\title{
Defects of genes encoding inhibitors of coagulation and their application in early miscarriage aetiology
}

\author{
Simonidesova $\mathrm{M}^{1}$, Simko $\mathrm{J}^{2}$, Holoman $\mathrm{K}^{3}$ \\ Department of Gynaecology and Obstetrics, Hospital of Povazska Bystrica, Slovakia. \\ msimonidesova@gmail.com
}

\begin{abstract}
Properly functioning coagulation in gravidity is not necessary only to provide the continuity of circulation in placenta. Today we recognize that proteins and cells of haemostasis in the maternal blood cooperate with the components of a coagulation cascade produced by embryonic trophoblast cells. Such coordination on the embryomaternal interface is necessary for an intact embryogenesis. Other findings discuss the ability of coagulation components to act also outside the hemocoagulation process, especially as signal molecules, regulators of immune reactions, cell proliferation and others. Haemostasis is thus a complex system and we still do not know all of its pathways. This is perhaps also the reason that in the case of known procoagulant mutations (FV Leiden, gene mutation for prothrombine G20210A) we cannot explain why some carriers suffer recurrent miscarriages and others have uncomplicated pregnancies. The expert community believes that the phenotype manifestation of these mutations in terms of pregnancy losses could be connected to the simultaneous presence (synergistic effect) of other polymorphisms of gene-encoding proteins of haemostasis or the lack thereof (antagonistic effect) (Ref. 59). Text in PDF www.elis.sk.

Key words: endothelial protein $\mathrm{C}$ receptor, thrombomodulin, tissue factor pathway inhibitor, protein $\mathrm{Z}$, recurrent pregnancy loss.
\end{abstract}

\begin{abstract}
Abbreviations: anti-EPCR - autoantibodies against EPCR, APC - activated protein C, p.c. - post coitum, EPCR - endothelial protein $\mathrm{C}$ receptor, sEPCR - soluble EPCR, F - factor, FII G20210A - prothrombin gene mutation, a $\mathrm{G}$ to $\mathrm{A}$ transition at nucleotide position 20210, FVL - FV Leiden, mutation in the FV gene, a G to A transition at nucleotide position $1691, \mathrm{Fv}^{\mathrm{Q}}$ - murine homologue of the FV Leiden mutation, PAR - protease-activated receptor/ receptors, $\mathrm{PC}$ - protein $\mathrm{C}$, $\operatorname{Procr}^{\delta}$ - mutation reduces expression of PROCR, gene for EPCR, PZ - protein Z, PZI - protein Z-dependent protease inhibitor, $\mathrm{TM}^{\text {pro }}$ - mutations reduces thrombomodulin expression and its ability to activate protein $\mathrm{C}, \mathrm{TF}$ - tissue factor, TFPI - tissue factor pathway inhibitor, TM - thrombomodulin, VTE - venous thromboembolism.
\end{abstract}

A balance between the coagulation and fibrinolytic system is necessary for an intact course of gravidity. Thus, impairment of the haemostatic system places a developing foetus at potential risk of gestational pathology. The first studies pointing out the effect of coagulation abnormalities on adverse pregnancy outcome were published in the mid-1990s. However, to date we cannot definitively state that carriers of the factor V Leiden (FVL) mutation

${ }^{1}$ Department of Gynaecology and Obstetrics, Hospital of Povazska Bystrica, Slovakia, ${ }^{2}$ Gendiagnostica Bratislava s.r.o., Molecular Biology Laboratory, Bratislava, Slovakia, ${ }^{3}$ IInd Department of Gynaecology and Obstetrics, University Hospital, Bratislava, Slovakia

Address for correspondence: M. Simonidesova, MD, Dept of Gynaecology and Obstetrics, Hospital of Povazska Bystrica, Nemocnicna 986, SK-01701 Povazska Bystrica, Slovakia

Phone: +421903257677 or gene mutations for prothrombine (FII) G2020A are connected with miscarriage risks in the first trimester. This is particularly due to the controversial results of studies and the fact that recurrent miscarriages occur only with a minority of the carriers of the aforementioned procoagulant mutations. The expert public believes that the phenotype manifestation of these mutations in the sense of pregnancy losses can be affected by other, newly studied polymorphisms of genes encoding proteins acting as haemostasis components.

In an effort to find such candidates, the scientists study in animal models the genes necessary for proper embryonic development or they test the genome in Genome-Wide Association Studies where attention is focused on single nucleotide polymorphisms (SNP) with thrombophilic potential.

\section{Protein C Pathway}

Thrombin plays a crucial role in haemostasis. In addition to its important coagulation function and ability to stimulate fibrinolysis, it activates signal pathways of certain cells. It also leads to the activation of the protein $\mathrm{C}$ pathway, after which it finishes its own production. The protein $\mathrm{C}$ pathway consists of a thrombin bond on thrombomodulin and the subsequent activation of protein $\mathrm{C}(\mathrm{PC})$. Thrombomodulin is the cofactor of thrombin, which speeds up this process. Efficiency is also increased by the binding between PC and the endothelial protein $\mathrm{C}$ receptor. After its release, the activated protein $\mathrm{C}$ (APC) together with its cofactor, protein $\mathrm{S}$, limits the amplification and progression of the coagulation cascade through factor Va and VIIIa degradation (1). 


\section{Protease-activated receptors}

Thrombin produces its effect on cells (thrombocytes, endothelial cells, trophoblast, inflammatory cells, and others) through protease-activated receptors (PAR) $(2,3)$. By bonding on the thrombocytes PAR, thrombin stimulates their secretion and aggregation. Mammal genome encodes four types of PAR (PAR1-PAR4); PAR2 is the only type that is not thrombin-activated. Human thrombocytes express PAR1 and PAR4 and mice thrombocytes express PAR3 and PAR4. While a low thrombin level is sufficient for PAR1 activation, PAR4 requires a high concentration (3). It has been proved that activated protein $\mathrm{C}$ is able to activate PAR1 on endothelial cells (4), which is probably one of the pathways of APC-mediated protective effect on endothelium. The potency of APC for PAR1 cleavage is approximately $10^{3}-10^{4}$-fold lower than thrombin; in other words, APC is a weak antagonist of PAR1 in comparison with thrombin (5). Thrombin itself is necessary for the presence of APC; therefore it was not clear why by the splitting of PAR1 elicits proinflammatory response, while by the activation of protein $\mathrm{C}$ has an opposed, protective effect on endothelium. It is assumed that in a physiologically quiescent state the high affinity of thrombin to thrombomodulin leads to a thrombin bond that is unable to activate PAR1. Simultaneously, the thrombin-TM complex activates the protein $\mathrm{C}$ pathway, which results in the APC splitting of PAR1 but with a potency that is distinctively lower than thrombin, by means of which the entire process has an ultimately protective effect. The basis for this is the presence of all three receptors adjacently in a cell membrane (6).

\section{Polymorphisms in the endothelial protein $\mathrm{C}$ receptor gene}

Endothelial protein C receptor (EPCR) is a type I transmembrane receptor that is particularly present on endothelial cells of large blood vessels and the placenta. Structurally shares homology with the proteins of major histocompatibility class I $(7,8,9)$. It is one of the inhibitors of coagulation in the protein $\mathrm{C}$ pathway. It amplifies $\mathrm{PC}$ activation by its ability to bind to the protein $\mathrm{C}$, which helps to orient protein $\mathrm{C}$ to the thrombin-thrombomodulin activation complex (1). It has been demonstrated that EPCR also serves as a cellular binding site for FVII/FVIIa. The FVIIa-EPCR bond inhibits FVIIa coagulation activity and facilitates the elimination of FVII from the endothelium through endocytosis (10). In addition to the cellular form bound to the endothelium, EPCR is also present as a circulating, soluble form. Soluble EPCR (sEP$\mathrm{CR}$ ) is released from the endothelium by the proteolytic cleavage of endothelial protein $\mathrm{C}$ receptor by metalloprotease with a loss of $4 \mathrm{kDA}$ part of molecule (11). It is naturally present in human plasma with an approximate concentration of $100 \mathrm{ng} / \mathrm{ml}$. Its level rises in the event of a systemic inflammation (12). It binds to PC and APC with the same affinity as EPCR (11), and it blocks the activation of protein $\mathrm{C}$ and the anticoagulation activity of APC (13). Thus, sEPCR has a predominantly procoagulant effect (14).

The human gene for EPCR, known as the PROCR gene, is localized on chromosome 20q11.2 (15). Its mutation, which causes a loss of function and drop of EPCR activity level on the membranes, should lead to a reduction of the anticoagulation effect with an acceleration of the risk of thrombosis and an impairment of the EPCR dependant processes. The disruption of the PROCR gene in murine embryonic stem cells resulted in the complete lethality of embryos with both defective alleles of PROCR (EPCR ${ }^{-/}$embryos) prior to embryonic day 10.5. The absence of EPCR production by giant trophoblast cells probably determined the fibrin depositions in their surroundings, which indicated thrombosis on the embryomaternal interface as the cause of the uniform lethality of the embryos. If low-molecular heparin was delivered to heterozygous mother mice $\left(\mathrm{EPCR}^{+/-}\right)$the fibrin deposition did not develop around the embryos. In spite of this, only approximately $25 \%$ of $\mathrm{EPCR}^{-/}$embryos survived the stage, in which they originally used to die out. It means that thrombosis is not the only cause of death for embryos. No $\mathrm{EPCR}^{-/}$embryo survived beyond embryonic day 15.5. If embryos were cultivated in vitro from embryonic day 7.5 without placentas in the course of four days; their development was uninterrupted at embryonic day 10.5 . The study revealed the information on the necessity of EPCR for a correct placenta functioning and development, the prevention of thrombosis on the fetomaternal interface, the correct course of interaction between mother and embryo, probably the importance of EPCR also for the regulation of other processes (such as immune reactions), and in a later stage of embryogenesis the fact that its expression is irreplaceable in the foetus' development of a vascular system. In the event of a reduced EPCR $\left(\mathrm{EPCR}^{+-}\right)$activity, the development of embryos was normal and the mouse did not show any postnatal thrombotic complications (9).

Complete EPCR deficiency among humans has not been described. Several polymorphisms affecting EPCR activity were identified within the framework of human PROCR. Four haplotypes are most frequent in Caucasians (14). Three haplotypes (A1, $\mathrm{A} 2, \mathrm{~A} 4)$ are determined by the presence of rare alleles containing single nucleotide polymorphisms, which are haplotype specific. Haplotype A2 consists of common alleles of all haplotype specific SNP (16).

Haplotype 1 (A1), marked by the presence of allele G4678C, in homozygous form leads to an increased activated protein $\mathrm{C}$ (APC) level, which is related to the described reduced risk of venous thromboembolism (17). The A4600G allele characterizes haplotype 3 (A3). This is associated with an increased plasmatic concentration of soluble EPCR (sEPCR) (18). In the case of this polymorphism, a higher share of SEPCR is probably determined by a conformation change in the EPCR molecule due to the amino acid change (Ser219Gly) and its subsequent enhanced susceptibility to metalloproteolytical splitting (16). Because sEPCR has a particularly procoagulant effect, we could expect an accelerated risk of venous thromboembolism (VTE) from increased rates of soluble EPCR in comparison to cellular EPCR. The thrombophilic potential of haplotype $\mathrm{A} 3$ however remains controversial. Medina et al (2004) confirmed an increased sEPCR load with the A3 haplotype, but they did not detect any increased risk of thrombosis (17). In the study population of Uitte de Willige et al (2004), the sEPCR level did not correlate with the level of thrombosis risk, but low levels were connected with a reduced incidence of VTE. 


\section{0-735}

Polymorphism 4 (A4) with a G3811A allele was described as a factor that slightly increases the risk of VTE (16).

Thus, no definite clinical effect of the abovementioned EPCR gene polymorphisms on haemostasis has been proved. However, their importance probably lies in their ability to modulate the phenotype expression of known thrombophilic mutations (FV Leiden, FII G20210A). In the study by Medina et al (2005), the presence of the A1 allele in FVL carriers significantly reduced the VTE risk $(p=0.002)(19)$. Navarro et al (2008) proved that the polymorphism of the A3 gene for EPCR was associated with an elevated VTE risk among carriers of the G20210A allele for prothrombin. Moreover, FII 620210A carriers with the A3 allele developed the first episode of VTE at an earlier age than carriers of the unaffected allele (18).

Neither the isolated haplotype A1 nor A3 showed an association with recurrent miscarriages in the study of similarly affected couples (20). However, it was demonstrated that the A1 haplotype reduced the risk by more than a half of recurrent miscarriage in the first trimester among patients with FVL (21).

Hurtado et al (2004) investigated the presence of antibodies against EPCR (anti-EPCR) among patients with antiphospholipid syndrome who had overcome venous and/or arterial thrombosis and patients with pregnancy loss after the $10^{\text {th }}$ week of gestation. Both groups showed significantly increased levels of anti-EPCR in comparison with the control population (22).

\section{Defects in the thrombomodulin gene}

Thrombomodulin (TM) is a transmembrane receptor that is located mainly on the luminal surface of endothelial cells of blood vessels (23). The thrombomodulin effect primarily occurs in the process of haemostasis as a protein $\mathrm{C}$ pathway anticoagulant, in which it functions as a thrombin receptor. Thus, through the bond on TM, thrombin loses its procoagulant activity and acquires a significantly increased ability to activate protein C (1.24).

The predisposition for arterial thrombosis was more often seen in cases of polymorphisms of thrombomodulin gene than in a similar disorder of the venous system (25-30).

Severe thrombomodulin deficiencies are incompatible with life (31). Healy et al (1995) studied the impact of the disruption of the thrombomodulin mice gene in embryonic stem cells producing $\mathrm{TM}$ deficiency. The outcome of the heterozygous genotype $\left(\mathrm{TM}^{+/}\right)$ was a $50 \%$ reduction of thrombomodulin activity, which however was not manifested through thrombotic phenotype. Homozygous embryos $\left(\mathrm{TM}^{--}\right)$died out before embryonic day 9.5 (32).

Isermann et al (2001) proved that the early lethality of $\mathrm{TM}^{--}$ mice embryos is caused by impairment of the function of the early placenta (yolk sac placenta) due to a deficit of thrombomodulin production by giant trophoblastic cells and parietal endoderm. If they allowed its limited expression only in these non-endothelial extraembryonic cells, embryos survived day 8.5 post coitum (p.c.) and continued to develop normally. However, the TM deficit in the endothelium of embryonic blood vessels caused an excessive activation of the embryonic coagulation system and the development of a lethal consumptive coagulopathy, which was incompa- tible with a survival beyond day 16 p.c. Vascularization was not altered. Thus, thrombomodulin is not necessary for the morphogenesis of blood vessels, but for haemostasis control. Whereas in non-endothelial extraembryonic tissue, it is probably necessary for the limitation of thrombin production and thus the regulation of signal pathways (see further) and in the embryonic endothelium of blood vessels in an effort to prevent excessive blood coagulation (33).

The essence of the necessity of thrombomodulin production is the permanent activation of the coagulation cascade by tissue factor at the fetomaternal interface. Opposed to a mature vascular system, where the tissue factor production is limited to vessel damage, trophoblast constitutively express this initiator of coagulation $(34,35)$. Thus, without inhibitors of coagulation, the unregulated activation of the coagulation cascade at the fetomaternal interface would occur. Isermann et al (2003) found that the thrombomodulin deficit $\left(\mathrm{TM}^{--}\right)$in trophoblast cells of an embryo led to damage of the placental function in two ways. On one hand, the excessive triggering of blood coagulation caused a pathological increase in the amount of fibrin degradation products inducing the extinction of trophoblast cells. In the second pathomechanism, they anticipated that the thrombomodulin-protein $\mathrm{C}$ pathway protected the placenta by the controlled activation of protease-activated receptors (PAR) (34).

In a subsequent study, the team of Sood et al (2008) proved that PAR4 deficiency in the mother or the absence of maternal thrombocytes enabled approximately one third of $\mathrm{TM}^{-/}$embryos to develop to term. This is probably based on the locally increased production of thrombin on the surface of the trophoblast due to the absence of TM, which through activation of PAR4 stimulates maternal thrombocytes. It is unclear how subsequently altered maternal plates caused the impairment of the placental function (35). There are hypotheses regarding the possible effect on the placental development by factors released from activated thrombocytes that affect angiogenesis (36) or modulating immune reactions. These studies demonstrate the ability of the fetal prothrombic state to influence the function of maternal thrombocytes to enable it to damage the placenta and the possibility of such mechanism being more essential in establishing embryonic lethality with $\mathrm{TM}^{-/-}$embryos as a fibrin formation. However, the activation of maternal thrombocytes only partially explains foetal losses in $\mathrm{TM}^{-/}$embryos. Unfortunately, even the induced absence of PAR1 or PAR2 on the surface of foetal trophoblastic cells did not bring any explanation; it did not protect $\mathrm{TM}^{-/-}$embryos from loss (35). In all probability, there are several mechanisms that determine the loss of embryos due to the unregulated activation of coagulation. In addition to the production of fibrin degrading products and the ability of thrombin to activate its own or maternal PAR, there are other factors that must be identified.

Stortoni et al (2010) measured the expression of the gene for TM (thrombomodulin mRNA) in human placental tissue acquired from spontaneous recurrent miscarriages and voluntary abortions as a controls. The expression of thrombomodulin in placental tissue from spontaneous miscarriages was reduced by $45 \%$ when compared to the control group (37). 


\section{Defects in the tissue factor pathway inhibitor gene}

Tissue factor pathway inhibitor (TFPI) is another inhibitor of blood coagulation. It directly inhibits factor Xa and through FXa the complex initiating blood coagulation, tissue factor (TF)-factor VIIa (FVIIa) (38). TFPI is mainly produced by endothelium (2, 39 ) and predominantly remains bound to its surface (40). A small amount of TFPI is bound to thrombocytes; the rest circulates free in plasma or in $80 \%$ as a complex with plasma lipoproteins. It seems that TFPI connected with lipoproteins has a weaker anticoagulant effect than free TFPI $(41,42)$. All of the aforementioned inhibitors of coagulation (EPCR, TM and TFPI) are also produced by human trophoblast cells (2).

Huang et al (1987), who examined the effect of the disruption of the exon 4 of TFPI gene encodes Kunitz domain-1 required for factor VIIa/tissue factor inhibition in mouse embryonic stem cells, demonstrated the participation of TFPI in embryogenesis. The complete deficiency of functional TFPI determined by the homozygous disruption of the TFPI gene TFPI $_{\mathrm{K} 1}^{--}$) led to embryonic lethality between embryonic days 9.5 and 11.5 with the yolk sac haemorrhage in $60 \%$ of cases; the rest died in a later gestation period, probably due to the uncontrolled origin of the FVIIa/TF complex with the development of consumptive coagulopathy and subsequent bleeding. Organogenesis was intact, which is evidence of the fact that TFPI is not necessary for the development of a specific tissue (43)

The theory regarding the uncontrolled FVIIa/TF activation as the cause of embryonic lethality in the case of TFPI deficiency is confirmed by the outcomes of the genetically induced VII factor (44) and tissue factor deficiency (45). Reduced FVII activity determined by its heterozygous or homozygous deficiency prevented $\mathrm{TFPI}^{-/-}$mice embryos from intrauterine lethality. The same result was achieved in the case of reduced TF expression.

Repeatedly, the elevated risk of thrombosis was expected due to TFPI reduction as the inhibitor of coagulation. However, the heterozygous state of TFPI (TFPI ${ }^{+/-}$) deficiency among mice revealed that even despite the $50 \%$ reduction of TFPI activity no prothrombotic phenotype was observed (43). Yet, the simultaneous incidence of the heterozygous genotype for TFPI deficiency and the homozygous carriage of murine homologue of the FV

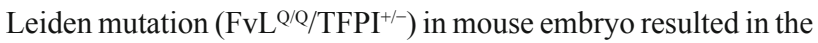
almost complete postnatal mortality of such mice with an extensive deposition of fibrin in the liver, lungs and kidneys indicating disseminated thrombosis. Individuals with isolated homozygosity for FV Leiden developed normally with a rare incidence of spontaneous thrombosis. Based on the above facts, the reduction of TFPI activity does not have to be manifested in terms of thrombotic phenotype, but combined with other thrombophilic states it can accelerate the procoagulation potential in mice (46).

The combination of reduced TFPI activity and the reduction of expression and activity of another anticoagulation protein, thrombomodulin $\left(\mathrm{TM}^{\text {pro }}\right)$, led to partial intrauterine lethality among mice embryos (TFPI $\left.{ }^{+-} / \mathrm{TM}^{\text {pro/pro }}\right)$. The mortality rate among embryos' was significantly increased if the mother was a carrier of the $\mathrm{TFPI}^{+/ /} / \mathrm{TM}^{\text {pro/+ }}$ or $\mathrm{TFPI}^{+/ /} / \mathrm{TM}^{\text {propro }}$ genotype. This proves the pos- sibility of the synergism of the maternal and embryonic prothrombotic genotype at embryomaternal interface, which consequently could be the cause of embryonic lethality in mice. An increased venous prothrombotic potential among $\mathrm{TFPI}^{+/-} / \mathrm{TM}^{\text {pro/pro }}$ individuals surviving into adulthood was recorded (47).

The effect of reduced TFPI level in humans has yet to be precisely defined. The complete absence of TFPI was not observed (47), which can indicate an embryonic lethal phenotype as with mice. Human foetal cells (epithelial and endothelial tissue in particular) produce TFPI from the 8th week of gestation, the placenta (syncytiotrophoblast, cytotrophoblast, vascular endothelium and extravillous trophoblast) from the 10th week (48). White el al (2010) proved that TFPI fraction produced by endothelium and myelomonocytic cells has no effect on embryogenesis (49). Probably it is the trophoblast playing a crucial role by production of inhibitors of coagulation, by which it acquires abilities similar to endothelial cells in the sense of regulation of haemostasis at foetomaternal interface (2).

Impact of the combination of a prothrombotic genotype and gene defect of inhibitor of coagulation (thrombomodulin) in mother and foetus

Sood et al (2007) studied the co-participation of the maternal and embryonic defects of haemostasis on the embryomaternal interface in the mouse model, and their impact on the fate of the embryo. Neither homozygosity for murine homologue of the FV Leiden $\left(\mathrm{Fv}^{\mathrm{Q}}\right)$, nor the isolated mutation of the gene for thrombomodulin leading to the reduction of its expression and ability to activate protein $\mathrm{C}\left(\mathrm{TM}^{\text {pro }}\right)$ affected fertility. However, their combination could lead to embryonic lethality depending on genotypes of the embryo and mother. For example, all $\mathrm{Fv}^{\mathrm{QQ}} / \mathrm{TM}^{\text {propro }}$ or $\mathrm{Fv}^{\mathrm{Q}^{+}}$/ $\mathrm{TM}^{\text {propro }}$ embryos in $\mathrm{Fv}^{\mathrm{QQ}} / \mathrm{TM}^{\text {pro+ }}$ mothers died out. Yet both embryonic genotypes were compatible with the embryo survival in mother suffering from $\mathrm{Fv}^{\mathrm{Q}^{+}} / \mathrm{TM}^{\text {propromutations. This demonstrates }}$ that the phenotype expression of genetically determined defects of haemostasis can be determined by both, maternal and foetal genotype.

Embryonic lethality was not attributed to placental thrombosis, as could be expected based on the unregulated coagulation due to the absence of an inhibitor. Again, it was based on the impairment of placental morphogenesis mediated by the PAR4 receptordependant activation of maternal thrombocytes. As it has been proved, platelet depletion at embryonic day 7.5 or elimination of PAR4 receptor from the mother was able to reverse the unfavourable impact on the development of the embryo (36).

\section{Defects in protein $\mathrm{Z}$ gene}

Protein Z (PZ) is a K vitamin-dependant glycoprotein produced by the liver. As a cofactor, it has an anticoagulant effect in complex with a protein Z-dependent protease inhibitor (PZI), which binds and deactivates the Xa factor. PZI is able to inhibit FXa on its own, but the cooperation with $\mathrm{PZ}$ accelerates the inhibition by a thousand times $(50,51)$. 
$730-735$

In addition to the relation to the increased risk of thrombosis in the arterial or venous system (52-54), we can also find studies that demonstrate the connection between the defects of protein $\mathrm{Z}$ gene or the presence of anti-Z antibodies with recurrent miscarriages.

Yin et al (2000) studied the results of protein Z deficiency in the case of the disruption of the $\mathrm{PZ}$ gene among mice. Isolated $\mathrm{PZ}$ deficiency $\left(\mathrm{PZ}^{--}\right)$did not manifest phenotypically and was compatible with normal survival. However, when combined with the homozygous genotype for murine homologue for the FV Leiden mutation $\left(\mathrm{Fv}^{\mathrm{Q} / \mathrm{Q}}\right)$, it caused intrauterine and perinatal thrombosis with consumptive coagulopathy, which led to almost total mortality. The extent of vascular thrombosis was reduced if only one $\mathrm{Z}$ protein allele was impaired $\left(\mathrm{PZ}^{+/-} / \mathrm{Fv}^{\mathrm{Q} / \mathrm{Q}}\right)$, or with the parallel presence of homozygous deficiency of protein $\mathrm{Z}$ and the heterozygous state for FV Leiden $\left(\mathrm{PZ}^{-/ /} / \mathrm{Fv}^{\mathrm{Q} /+)}(55)\right.$.

When studying the influence of protein $\mathrm{Z}$ deficiency on recurrent early miscarriages or foetal losses, a significant number of $\mathrm{PZ}$ deficiencies were observed in women with early pregnancy losses $(p<0.001)(56)$. It has been proven that antibodies against protein $\mathrm{Z}$ are also connected with recurrent miscarriages. Sater et al (2011) detected their significant increase among patients affected in such way in comparison with the control group ( $p<0.001)(51)$.

When studying the effect of intron F G79A polymorphism in the protein $\mathrm{Z}$ gene on recurrent spontaneous miscarriages, Dossenbach-Glaninger et al (2008) described its protective effect and even the reduction of the risk when other genetically determined thrombophilia were simultaneously present (57). On the contrary, Topalidou et al (2009) did not find any significant difference in the incidence of the F79A allele in comparison with fertile women of the control group (58). Grandone et al (2008) recorded a significant connection between C G-42A gene variant of protein $\mathrm{Z}$ and foetal losses (59).

\section{Conclusion}

It is probable that the haemostatic aetiology of recurrent miscarriages is complex and its expression requires a combination of specific defects with a synergic effect or conversely, the antagonistic effect of certain polymorphism may lead to phenotypic masking of other mutation. By revealing the ability of trophoblast cells to even produce the regulators of coagulation, the embryonic/foetal genotype also acts as an object of interest. The study of the genes encoding proteins of coagulant and fibrinolytic cascade and the mutual relations of their defects could be helpful in understanding how the congenital defects of haemostasis affect the early stage of pregnancy.

\section{References}

1. Dahlbäck B. Blood coagulation and its regulation by anticoagulant pathways: genetic pathogenesis of bleeding and thrombotic diseases. J Intern Med 2005; 257 (3): 209-223.

2. Sood R, Kalloway S, Mast AE, Hillard CJ, Weiler H. Fetomaternal cross talk in the placental vascular bed: control of coagulation by trophoblast cells. Blood 2006; 107 (8): 3173-3180.
3. Coughlin SR. Protease-activated receptors in hemostasis, thrombosis and vascular biology. J Thromb Haemost 2005; 3 (8): 1800-1814.

4. Riewald M, Petrovan RJ, Donner A, Mueller BM, Ruf W. Activation of endothelial cell protease activated receptor 1 by the protein $\mathrm{C}$ pathway. Science 2002; 296 (5574): 1880-1882.

5. Ludeman MJ, Kataoka H, Srinivasan Y, Esmon NL, Esmon CT, Coughlin SR. PAR1 cleavage and signaling in response to activated protein $\mathrm{C}$ and thrombin. J Biol Chem 2005; 280 (13): 13122-13128.

6. Bae JS, Yang L, Rezaie AR. Receptors of the protein C activation and activated protein $\mathrm{C}$ signaling pathways are colocalized in lipid rafts of endothelial cells. Proc Natl Acad Sci USA 2007; 104 (8): 2867-2672.

7. Fukudome K, Esmon CT. Identification, cloning, and regulation of a novel endothelial cell protein C/activated protein C receptor. J Biol Chem 1994; 269 (42): 26486-26491.

8. Laszik Z, Mitro A, Taylor FB Jr, Ferrell G, Esmon CT. Human protein $\mathrm{C}$ receptor is present primarily on endothelium of large blood vessels: implications for the control of the protein C pathway. Circulation 1997; 96 (10): 3633-3640.

9. Gu JM, Crawley JT, Ferrell G et al. Disruption of the endothelial cell protein $\mathrm{C}$ receptor gene in mice causes placental thrombosis and early embryonic lethality. J Biol Chem 2002; 277 (45): 43335-43343.

10. Ghosh S, Pendurthi UR, Steinoe A, Esmon CT, Rao LV. Endothelial cell protein $\mathrm{C}$ receptor acts as a cellular receptor for factor VIIa on endothelium. J Biol Chem 2007; 282 (16): 11849-11857.

11. Xu J, Qu D, Esmon NL, Esmon CT. Metalloproteolytic release of endothelial cell protein C receptor. J Biol Chem 2000; 275 (8): 6038-6044.

12. Kurosawa S, Stearns-Kurosawa DJ, Carson CW, D‘Angelo A, Della Valle P, Esmon CT. Plasma levels of endothelial cell protein $\mathrm{C}$ receptor are elevated in patients with sepsis and systemic lupus erythematosus: lack of correlation with thrombomodulin suggests involvement of different pathological processes. Blood 1998; 91 (2): 725-727.

13. Liaw PC, Neuenschwander PF, Smirnov MD, Esmon CT. Mechanisms by which soluble endothelial cell protein $\mathrm{C}$ receptor modulates protein $\mathrm{C}$ and activated protein C function. J Biol Chem 2000; 275 (8): 5447-5452.

14. Gadrille S. Endothelial cell protein and the risk of venous thrombosis. Haematologica 2008; 93 (6): 812-816.

15. Simmonds RE, Lane DA. Structural and functional implications of the intron/exon organization of the human endothelial cell protein C/activated protein $\mathrm{C}$ receptor (EPCR) gene: comparison with the structure of CD1/major histocompatibility complex alpha1 and alpha2 domains. Blood 1999; 94 (2): 632-641.

16. Uitte de Willige S, van Marion V, Rosendaal FR, Vos HL, de Visser MCH, Bertina RM. Haplotypes of the EPCR gene, plasma sEPCR levels and the risk of deep venous thrombosis. J Thromb Haemost 2004; 2 (8): 1305-1310.

17. Medina P, Navarro S, Estellés A et al. Contribution of polymorphisms in the endothelial protein $\mathrm{C}$ receptor gene to soluble endothelial protein $\mathrm{C}$ receptor and circulating activated protein $\mathrm{C}$ levels and thrombotic risk. Thromb Haemost 2004; 91 (5): 1305-1310.

18. Navarro S, Medina P, Mira Y et al. Haplotypes of the EPCR gene, prothrombin levels, and the risk of venous thrombosis in carriers of the prothrombin G20210A mutation. Haematologica 2008; 93 (6): 885-891.

19. Medina P, Navarro S, Estellés A, Vayá A, Bertina RM, España F. Influence of the $4600 \mathrm{~A} / \mathrm{G}$ and $4678 \mathrm{G} / \mathrm{C}$ polymorphisms in the endothelial protein $\mathrm{C}$ receptor (EPCR) gene on the risk of venous thromboembolism in carriers of factor V Leiden. Thromb Haemost 2005; 94 (2): 389-394.

20. Kaare M, Ulander V-M, Painter JN, Ahvenainen T, Kaaja R, Aittomäki K. Variations in the thrombomodulin and endothelial protein $\mathrm{C}$ receptor genes in couples with recurrent miscarriage. Hum Reprod 2007; 22 (3): 864-868. 
21. Hopmeier P, Puehringer H, van Trotsenburg M, Atamaniuk J, Oberkanins C, Dossenbach-Glaninger A. Association of endothelial protein C receptor haplotypes, factor $\mathrm{V}$ Leiden and recurrent first trimester pregnancy loss. Clin Bioch 2008; 41 (12): 1022-1024.

22. Hurtado V, Montes R, Gris J-C et al. Autoantibodies against EPCR are found in antiphospholipid syndrome and are a risk factor for fetal death. Blood 2004; 104 (5): 1369-1374.

23. Esmon CT. Regulation of blood coagulation. Biochim Biophys Acta 2000; 1477 (1-2): 349-360.

24. Lane DA, Grant PJ. Role of hemostatic gene polymorphisms in venous and arterial thrombotic disease. Blood 2000; 95 (5): 1517-1532.

25. Li YH, Chen JH, Wu HL et al. G-33A mutation in the promoter region of thrombomodulin gene and its association with coronary artery disease and plasma soluble thrombomodulin levels. Am J Cardiol 2000; 85 (1): 8-12.

26. Le Flem L, Mennen L, Aubry ML et al. Thrombomodulin promoter mutations, venous thrombosis, and varicose veins. Arterioscler Thromb Vasc Biol 2001; 21 (3): 445-451.

27. Faioni EM, Franchi F, Castaman G, Biguzzi E, Rodeghiero F. Mutations in the thrombomodulin gene are rare in patients with severe thrombophilia. $\mathrm{Br}$ J Haematol 2002; 118 (2): 595-599.

28. Cole JW, Roberts SC, Gallagher M et al. Thrombomodulin Ala455Val polymorphism and the risk of cerebral infarction in a biracial population: the stroke prevention in young women study. BMC Neurol 2004; 4 (1): 21.

29. Heit JA, Petterson TM, Owen WG, Burke JP, DE Andrade M, Melton LJ 3rd. Thrombomodulin gene polymorphisms or haplotypes as potential risk factors for venous thromboembolism: a population-based case-control study. J Thromb Haemost 2005; 3 (4): 710-717.

30. Lobato RL, White WD, Mathew JP et al. Thrombomodulin gene variants are associated with increased mortality after coronary artery bypass surgery in replicated analyses. Circulation 2011; 124 (11 Suppl): 143-148.

31. Anastasiou G, Gialeraki A, Merkouri E, Politou M, Travlou A. Thrombomodulin as a regulator of the anticoagulant pathway: implication in the development of thrombosis. Blood Coagul Fibrinolysis 2012; 23 (1): 1-10.

32. Healy AM, Rayburn HB, Rosenberg RD, Weiler H. Absence of the bloodclotting regulator thrombomodulin causes embryonic lethality in mice before development of a functional cardiovascular system. Proc Natl Acad Sci U S A 1995; 92 (3): 850-854.

33. Isermann B, Hendrickson SB, Hutley K, Wing M, Weiler H. Tissuerestricted expression of thrombomodulin in the placenta rescues thrombomodulin-deficient mice from early lethality and reveals a secondary developmental block. Development 2001; 128 (6): 827-838.

34. Isermann B, Sood R, Pawlinski R et al. The thrombomodulin-protein C system is essential for the maintenance of pregnancy. Nat Med 2003; 9 (3):331-337.

35. Sood R, Sholl L, Isermann B, Zogg M, Coughlin SR, Weiler H. Maternal Par4 and platelets contribute to defective placenta formation in mouse embryos lacking thrombomodulin. Blood 2008; 112 (3): 585-591.

36. Sood R, Zogg M, Westrick RJ et al. Fetal gene defects precipitate platelet-mediated pregnancy failure in factor V Leiden mothers. J Exp Med 2007; 204 (5): 1049-1056.

37. Stortoni P, Cecati M, Giannubilo SR et al. Placental thrombomodulin expression in recurrent miscarriage. Reprod Biol Endocrinol 2010; 8: 1.

38. Broze GJ Jr. Tissue factor pathway inhibitor and the current concept of blood coagulation. Blood Coagul Fibrinolysis 1995; Suppl 1: 7-13.

39. Bajaj MS, Kuppuswamy MN, Saito H, Spitzer SG, Bajaj SP. Cultured normal human hepatocytes do not synthesize lipoprotein-associated coagulation inhibitor: evidence that endothelium is the principal site of its synthesis. Proc Natl Acad Sci U S A 1990; 87 (22): 8869-8873.

40. Sandset PM. Tissue factor pathway inhibitor (TFPI) - an update. Haemostasis 1996; 26: 154-165.
41. Novotny WF, Girard TJ, Miletich JP, Broze GJ Jr. Purification and characterization of the lipoprotein-associated coagulation inhibitor from human plasma. J Biol Chem 1989; 264 (31): 18832-18837.

42. Lindahl AK, Sandset PM, Abildgaard U. The present status of tissue factor pathway inhibitor. Blood Coagul Fibrinolysis 1992; 3 (4): 439-449.

43. Huang ZF, Higuchi D, Lasky N, Broze GJ Jr. Tissue factor pathway inhibitor gene disruption produces intrauterine lethality in mice. Blood 1997; 90 (3): 944-951.

44. Chan JC, Carmeliet P, Moons L et al. Factor VII deficiency rescues the intrauterine lethality in mice associated with a tissue factor pathway inhibitor deficit. J Clin Invest 1999; 103 (4): 475-482.

45. Pedersen B, Holscher T, Sato Y, Pawlinski R, Mackman N. A balance between tissue factor and tissue factor pathway inhibitor is required for embryonic development and hemostasis in adult mice. Blood 2005; 105 (7): 2777-2782.

46. Eitzman DT, Westrick RJ, Bi X et al. Lethal perinatal thrombosis in mice resulting from the interaction of tissue factor pathway inhibitor deficiency and factor V Leiden. Circulation 2002; 105 (18): 2139-2142.

47. Maroney SA, Cooley BC, Sood R, Weiler H, Mast AE. Combined tissue factor pathway inhibitor and thrombomodulin deficiency produces an augmented hypercoagulable state with tissue-specific fibrin deposition. J Thromb Haemost 2008; 6 (1): 111-117.

48. Edstrom CS, Calhoun DA, Christensen RD. Expression of tissue factor pathway inhibitor in human fetal and placental tissues. Early Hum Dev 2000; 59 (2): 77-84.

49. White TA, Johnson T, Zarzhevsky $\mathbf{N}$ et al. Endothelial-derived tissue factor pathway inhibitor regulates arterial thrombosis but is not required for development or hemostasis. Blood 2010; 116 (10): 1787-1794.

50. Han X, Fiehler R, Broze GJ Jr. Characterization of the protein Z-dependent protease inhibitor. Blood 2000; 96 (9): 3049-3055.

51. Sater MS, Finan RR, Al-Hammad SA, Mohammed FA, Issa AA, Almawi WY. High frequency of anti-protein Z IgM and IgG autoantibodies in women with idiopatic recurrent spontaneous miscarriage. Am J Reprod Immunol 2011; 65 (5): 526-531.

52. Heeb MJ, Paganini-Hill A, Griffin JH, Fisher M. Low protein Z levels and risk of ischemic stroke: differences by diabetic status and gender. Blood Cells Mol Dis 2002; 29 (2): 139-144.

53. Fedi S, Sofi F, Brogi $\mathbf{D}$ et al. Low protein $Z$ plasma levels are independently associated with acute coronary syndromes. Thromb Haemost 2003; 90 (6): 1173-1178.

54. Sofi F, Cesari F, Abbate R, Gensini GF, Broze G Jr, Fedi S. A metaanalysis of potential risks of low levels of protein $\mathrm{Z}$ for diseases related to vascular thrombosis. Thromb Haemost 2010; 103 (4): 749-756.

55. Yin Z-F, Huang Z-F, Cui $\mathbf{J}$ et al. Prothrombotic phenotype of protein Z deficiency. Proc Natl Acad Sci U S A 2000; 97 (12): 6734-6738.

56. Gris J-C, Queéré I, Dechaud H et al. High frequency of protein $Z$ deficiency in patients with unexplained early fetal loss. Blood 2002; 99 (7): 2606-2608.

57. Dossenbach-Glaninger A, van Trotsenburg M, Helmer H, Oberkanins C, Hopmeier P. Association of the protein Z intron F G79A gene polymorphism with recurrent pregnancy loss. Fertil Steril 2008; 90 (4): 1155-1160.

58. Topalidou M, Effraimidou S, Farmakiotis D et al. Low protein Z levels, but not the intron F G79A polymorphism, are associated with unexplained pregnancy loss. Thromb Res 2009; 124 (1): 24-27.

59. Grandone E, Colaizzo D, Cappucci F, D‘Ambrosio RL, Vecchione G, Margaglione M. An unreported mutation within protein $Z$ gene is associated with very low protein levels in women with fetal loss. Fertil Steril 2008; 90 (3): 864-865.

Received April 25, 2013. Accepted February 15, 2014. 